\title{
Energy reserves in Brevicoryne brassicae (Lin.) (Homoptera: Aphididae) instars and their effect on predation and longevity of three coccinellid species under laboratory conditions
}

Salama Ibrahim Askar ${ }^{1}$ and Monir Mohamed El Husseini ${ }^{2 *}$

\begin{abstract}
Background: Contents of carbohydrates, protein, and lipids in tissues of insect prey constitute the required energy reserve utilized by their predators. Their amounts define the preference of the predator to certain prey on which its biological performance is the optimum. Feeding preferences and longevity of the 3 coccinellid beetles; Coccinella septempunctata L., C. undecimpunctata L., and Scymnus interruptus L. were studied in relation to energy reserve in tissues of the cabbage aphid, Brevicoryne brassicae (Lin.).

Main body: The level of energy reserve increased with increasing of aphid nymphal instars showing the highest in 4th instar $(0.10844 \mathrm{cal} / \mathrm{mg})$. Lipids and carbohydrates represented the highest energy reserve average rate in $B$. brassicae adults $(0.29139$ and $0.07404 \mathrm{cal} / \mathrm{mg})$, respectively. C. septempunctata larval stage recorded the highest efficiency in daily predation (89.42 prey), when fed on 1st instar nymphs of the aphid. It required 21 days when fed on the 3rd nymphal instar of $B$. brassicae. S. interruptus larval stage reflected the lowest consumption and longevity in predation where it consumed less than 69.25 prey/day and lasted a period less than 17.5 days. Generation time for $C$. undecimpunctata lasted the longest (20.89 days) when fed on B. brassicae 1st nymphal instar. It was decreased in S. interruptus recording (12.22 days) when fed on B. brassicae 3rd nymphal instar.

Conclusion: Only C. septempunctata was efficient in predation and its biological performance was the best compared to the other tested coccinellid species. Use of C. septempunctata can be recommended when applying biological control programs in the field against the cabbage aphid.
\end{abstract}

Keywords: Energy reserves, Brevicoryne brassicae, Coccinellidae, Predation

\footnotetext{
*Correspondence: monir.elhusseini@agr.cu.edu.eg

${ }^{2}$ Center of Biological Control \& IPM, Faculty of Agriculture, Cairo University,

Giza, Egypt

Full list of author information is available at the end of the article
}

(c) The Author(s). 2020 Open Access This article is licensed under a Creative Commons Attribution 4.0 International License, which permits use, sharing, adaptation, distribution and reproduction in any medium or format, as long as you give appropriate credit to the original author(s) and the source, provide a link to the Creative Commons licence, and indicate if changes were made. The images or other third party material in this article are included in the article's Creative Commons licence, unless indicated otherwise in a credit line to the material. If material is not included in the article's Creative Commons licence and your intended use is not permitted by statutory regulation or exceeds the permitted use, you will need to obtain permission directly from the copyright holder. To view a copy of this licence, visit http://creativecommons.org/licenses/by/4.0/. 


\section{Background}

Predators have a great potential to keep the population of aphid under control (Askar et al. 2013). The coccinellids represent an important group of predators that manage pests' populations throughout the world (Obrycki and Kring 1998). Naturally, coccinellids feed on aphids, thrips, spider mites, and various soft-bodied insects and their eggs. In aphids, many factors can affect the prey preferences of the coccinellids, including the mobility and defense reaction of the prey (Provost et al. 2006), morphological characters and previous feeding experience (Khan and Rafique 2004), predator and prey size (Thompson 1975), and abundance of prey (Soares et al. 2004). Many species of aphids are characterized by production of some biological properties such as susceptibility to natural enemies (Brandele and Weisser 2001). Information pertaining to the biological parameters and feeding preference of predatory beetle on different aphid instars is essential for assessing the potential rate of increase in the population and its predation as a biological control agent.

The aim of this study was to determine the effect of energy reserves of Brevicoryne brassicae (L.) instars on feeding preferences and longevity of 3 coccinellid beetles as well as measuring the energy reserves quantitatively including water-soluble carbohydrates, lipids and proteins in different instars of B. brassicae under laboratory conditions.

\section{Main text}

\section{Material and methods}

Cabbage plants were cultivated in plastic pots $(25 \mathrm{~cm}$ diameter, $20 \mathrm{~cm}$ high), kept in net cages of $50 \times 60 \times 60$ $\mathrm{cm}$ under a climate-controlled room of $25 \pm 2{ }^{\circ} \mathrm{C}, 65 \pm$ 5\% RH and a 14L:10D photoperiod. One-month-old plants, with 5-7 leaves, were used for rearing the cabbage aphid species, B. brassicae.

\section{Source of the aphid and the coccinellid species}

Infested plants with the cabbage aphid, B. brassicae infestation were collected from cultivated cabbage fields in ElBehera Governorate, Egypt. The collected aphids were colonized in the laboratory on cultivated cabbage plants and kept at $25 \pm 2{ }^{\circ} \mathrm{C}, 65 \pm 5 \% \mathrm{RH}$ and 14L:10D photoperiod. Under the same laboratory conditions, the selected 3 coccinellid predators, Coccinella septempunctata L., C. undecimpunctata L., and Scymnus interruptus L. were collected from the field, reared, and colonized on cabbage aphid. They were reared for one generation before their immature and mature feeding individuals being used in the experimental study.

\section{Quantitative measuring of the energy reserves}

To determine the different energy reserves (lipids, proteins, and carbohydrates), B. brassicae adults and nymphal instars were selected randomly, then separately homogenized for $30 \mathrm{~s}$ in $180 \mu \mathrm{l}$ of aqueous lysis buffer solution (100 mM KH2PO4, $1 \mathrm{mM}$ dithiothreitol, and 1 MM ethylenediamine tetra acetic acid, $\mathrm{pH} 7.4$ ), using a plastic micro-pestle (Lowry et al. 1951). Three replicates of each determination in the following assays were analyzed. According to Lowry et al. (1951), protein concentrations in homogenates of the whole body of the aphid instars were measured. Bovine serum albumin at appropriate concentrations was used as the standard. Total carbohydrates were dissolved by addition of $20 \mu \mathrm{l}$ of sodium sulfate solution (20\%) to 180 homogenates (Van Handel and Day 1988). Total lipid and water-soluble carbohydrates were solubilized by mixing the solution with $1500 \mu \mathrm{L}$ of a chloroform-methanol solution (1:2 v/ v) (Van Handel and Day 1988). Each sample was then centrifuged at $16,000 \mathrm{rpm}$ for $15 \mathrm{~min}$ at $4{ }^{\circ} \mathrm{C}$. The supernatant was transferred to a new micro-tube for watersoluble carbohydrate determination. The pellet was used for the determination of the glycogen content. Vanillin reagent and cholesterol (as the standard) were used for measuring total lipid content (Van Handel 1985). One hundred microliters of the supernatant from centrifuged chloroform-methanol solution was transferred into new micro-tubes and heated until complete solvent evaporation. Ten microliters of $98 \%$ euphoric acid was added to each micro-tube, which incubated at $90{ }^{\circ} \mathrm{C}$ for $2 \mathrm{~min}$. Vanillin reagent $(190 \mu \mathrm{l})$ was added to each ice precooled micro-tube. Absorbance was determined at 540 $\mathrm{nm}$ after $15 \mathrm{~min}$ incubation at room temperature. Different energy reserves for lipids, proteins, and carbohydrates were converted into energetic equivalents according to Ahsaei et al. (2013). Feeding performance and longevity of the coccinellid species were defined.

\section{Predation efficiency and longevity of the coccinellid beetles}

To estimate some biological parameters, prey consumption, longevity of the 3 coccinellid species, and the effect of aphid prey instars on these measures were performed. The experiments were conducted, using separately the second generation of each predatory species. Cabbage leaves were cut into pieces and placed in glass Petri dishes (9-cm diameter) containing 2\% agar at the bottom. Singly, each aphid nymphal instar was counted and transferred into a glass Petri dish to feed on cabbage leaves. After hatching of the predatory species, larvae were collected with a fine camel hairbrush and placed into a new glass jar. Each larval instar was provided daily by a known number of aphids (at least 150 individual prey) at different adult and nymphal instars for feeding the predator. During development of larval instars and adults, remaining number of aphids were daily counted and offered other known number to give each predator instar enough prey number till developing to the next 
instar. Feeding potential was recorded by counting the number of aphids consumed by 1st, 2nd, 3rd, and 4th instars for the tested coccinellids up till the adult started to lay eggs. Five replicates for each treatment were conducted, each with 5 larvae. Aphids' prey was also provided by enough numbers of the same instar for each predatory instar. Control units were free from any predator and were also inspected daily to record the increase of the progeny or of the mortality of aphid prey in order to correct the number of actual consumed aphids in each experiment. Data were collected twice daily (each $12 \mathrm{~h}$ ) and corrected with that of the control (Abbott 1925) to evaluate feeding capacity and longevity of each coccinellid instar under the influence of different instars of aphid prey. Experiments using the same design were conducted with $C$. undecimpunctata and S. interruptus adults and larval instars.

\section{Statistical analysis}

Data were analyzed using (SAS Institute 1988) to test the significance and estimate LSD among treatments. The correlation relationships and correlation coefficient values between predator and prey age, was estimated as the regression line relationship was calculated by the regression line equation.

\section{Results and discussion}

\section{Energy reserves in $B$. brassicae nymphal instars}

The energy reserves encountered the carbohydrates, proteins and lipids in B. brassicae nymphal instars. The average energy reserves in instars differed significantly $(P>0.05)$ (Table 1$)$. The level of portions increased by increasing age of the nymphal instar, recording the highest in 4th instar $(0.10844 \mathrm{cal} / \mathrm{mg})$. The results also showed that the energy presented in the form of lipids and carbohydrates increased by the advancement of the nymph age, till they recorded the highest average rate in B. brassicae adults with $(0.29139$ and $0.07404 \mathrm{cal} / \mathrm{mg})$, respectively. The general energy level increased as the nymphs advanced in age to record the highest in $B$. brassicae adults with $0.473839 \mathrm{cal} / \mathrm{mg}$. In contrast, the average protein energy reserves in $B$. brassicae aphid over their lifetime was lower than the general average level of lipids, but at the same time it was higher than the one of carbohydrates, where the overall average scored $(0.375227 \mathrm{cal} / \mathrm{mg})$ for all ages and during the life cycle of aphids (Table 1). Results also showed that a convergence in the energy level between the 4th nymphal instars and adults, other a convergence between the 2nd and 3rd nymphal instars. The results reflected that lipids were the most abundant energy reserve $(63.67 \%)$, followed by proteins $(24.15 \%)$ and then soluble carbohydrates $(12.18 \%)$. The results also revealed that protein and lipids were the most important storage fuels of insects and were utilized more frequently than other reserves to obtain energy for muscular activity, so there were significantly higher contents of lipids, but lower contents of proteins and soluble carbohydrates. Obtained data are nearly in accordance to those of Ahsaei et al. (2013) who found in the pea aphid, Acyrthosiphon pisum, a higher percentage content of water-soluble carbohydrates and lipids in the red clones. Thus, this aphid species needs more lipids and carbohydrates to fuel their movements and flight. Gupta and Kumar (2017) reported that protein concentration values were directly proportional to the efficiency of artificial diets for C. septempunctata larvae.

\section{Predation efficiency and longevity of C. septempunctata}

Data presented in Table 2 showed longevity and feeding consumption of $C$. septempunctata different stages, when fed on different instars of B. brassicae. Number of consumed prey increased gradually as the age of predator and the prey increased. The predator lifespan had non-significant effect on different ages of prey (Table 2). The 1st instar larvae of C. septempunctata consumed a highest number of 1st instar of the aphid (42.33 daily). Feeding efficiency decreased gradually as well as the prey increased in age. On other hand, 2nd and 3rd instars showed non-significant variations among all prey instars.

Table 1 Average energy equivalents (cal/mg) of the proteins, lipids and carbohydrates in B. brassicae instars

\begin{tabular}{|c|c|c|c|c|c|c|c|}
\hline \multirow{2}{*}{$\begin{array}{l}\text { Individual } \\
B . \\
\text { brassicae } \\
\text { instar }\end{array}$} & \multicolumn{2}{|l|}{ Proteins } & \multicolumn{2}{|l|}{ Lipids } & \multicolumn{2}{|c|}{ Carbohydrates } & \multirow{2}{*}{$\begin{array}{l}\text { Total } \\
\text { energy }\end{array}$} \\
\hline & (cal/mg) & $\%$ & (cal/mg) & $\%$ & (cal/mg) & $\%$ & \\
\hline $1 s t$ & $0.05685 \mathrm{a}$ & 22.91 & $0.17006 \mathrm{a}$ & 68.53 & $0.02126 \mathrm{a}$ & 8.57 & $0.248161 \mathrm{a}$ \\
\hline $2 n d$ & $0.08622 \mathrm{~b}$ & 25.33 & $0.21807 b$ & 64.07 & $0.03607 \mathrm{~b}$ & 10.60 & $0.340355 b$ \\
\hline $3 r d$ & $0.10318 b c$ & 26.21 & $0.24577 b$ & 62.44 & $0.04466 \mathrm{~b}$ & 11.35 & $0.393617 \mathrm{c}$ \\
\hline 4 th & $0.10844 \mathrm{c}$ & 25.21 & $0.26918 \mathrm{bc}$ & 62.58 & $0.05255 c$ & 12.22 & $0.430161 \mathrm{~d}$ \\
\hline Adult & $0.0984 b c$ & 21.22 & $0.29139 c$ & 62.82 & $0.07404 \mathrm{~d}$ & 15.96 & $0.473839 d$ \\
\hline Mean & 0.09062 & 24.15 & 0.23889 & 63.67 & 0.04572 & 12.18 & 0.375227 \\
\hline LSD 5\% & 0.04221 & 2.09 & 0.04913 & 2.79 & 0.06022 & 1.92 & 0.05611 \\
\hline
\end{tabular}


Table 2 Effect of B. brassicae stages on C. septempunctata biological parameters

\begin{tabular}{|c|c|c|c|c|c|c|c|c|c|c|c|c|c|c|}
\hline \multirow{3}{*}{$\begin{array}{l}\text { B. } \\
\text { brassicae } \\
\text { instar }\end{array}$} & \multicolumn{14}{|c|}{ C. septempunctata instars } \\
\hline & \multicolumn{2}{|l|}{$1 \mathrm{st}$} & \multicolumn{2}{|l|}{ 2nd } & \multicolumn{2}{|l|}{3 rd } & \multicolumn{2}{|l|}{ 4th } & \multicolumn{2}{|l|}{ Pupa } & \multicolumn{2}{|l|}{ Adult } & \multicolumn{2}{|c|}{ Pre-oviposition } \\
\hline & Long.* & Prey** & Long. & Prey & Long. & Prey & Long. & Prey & Long. & Prey & Long. & Prey & Long. & Prey \\
\hline $1 \mathrm{st}$ & $3.17 b c$ & $42.33 \mathrm{a}$ & $5.17 b$ & $82.00 \mathrm{a}$ & $6.83 a$ & 96.67 a & $8.67 \mathrm{a}$ & $136.67 \mathrm{a}$ & $6.17 b$ & 0.00 & $28.67 \mathrm{ab}$ & $167.00 \mathrm{a}$ & $3.17 \mathrm{a}$ & $167.00 \mathrm{a}$ \\
\hline 2nd & $4.17 \mathrm{a}$ & 34.33 b & $5.50 \mathrm{ab}$ & $69.67 \mathrm{~b}$ & $6.83 a$ & $77.00 \mathrm{~b}$ & $7.83 \mathrm{bc}$ & $132.33 \mathrm{a}$ & $6.17 \mathrm{~b}$ & 0.00 & $29.33 a b$ & $154.33 \mathrm{ab}$ & $3.17 \mathrm{a}$ & $154.33 \mathrm{ab}$ \\
\hline $3 \mathrm{rd}$ & $2.83 \mathrm{C}$ & $25.33 c$ & $4.67 c$ & $61.67 c$ & $6.17 b$ & $59.67 \mathrm{C}$ & $7.33 c$ & $123.00 \mathrm{ab}$ & $5.83 \mathrm{~b}$ & 0.00 & $27.67 b$ & $143.67 b$ & $2.83 a$ & $143.67 b$ \\
\hline 4 th & $3.33 b$ & $24.33 \mathrm{~cd}$ & $5.67 \mathrm{a}$ & $57.33 \mathrm{c}$ & $6.17 b$ & $56.67 c$ & $8.17 \mathrm{ab}$ & $114.33 b c$ & $7.00 \mathrm{a}$ & 0.00 & $28.67 \mathrm{ab}$ & $126.67 \mathrm{c}$ & $3.17 \mathrm{a}$ & $126.67 \mathrm{c}$ \\
\hline Adult & $2.83 c$ & $19.67 d$ & $5.67 \mathrm{a}$ & $59.00 \mathrm{c}$ & $6.67 \mathrm{ab}$ & $54.00 \mathrm{C}$ & 8.67 a & 107.33 & $6.83 a$ & 0.00 & 32.33 a & 118.33 C & 3.33 a & 118.33 c \\
\hline LSD 5\% & 0.42 & 0.09 & 0.49 & 4.79 & 0.60 & 12.92 & 0.56 & $14.17 c$ & 0.62 & 0.00 & 4.38 & 14.09 & 0.52 & 14.09 \\
\hline
\end{tabular}

*Lonng. = longevity (/days), ${ }^{* *}$ Prey = number of consumed prey

Fourth larval instar consumed a high number of 1st and 2nd aphid instars (136.67 and 132.33) individuals daily, respectively. Meanwhile, feeding consumption decreased gradually recording (107.33), when fed on aphid adults. Before starting egg laying, C. septempunctata consumed all the aphid instars with a highest capacity on 1st nymphal instar of 167.00 that decreased gradually in 2nd, 3rd, 4th instars and adults, respectively. Concerning lifespan and longevity of $C$. septempunctata, the 1st larval instar lasted an average period of 4.17 days, when fed on $B$. brassicae instars. This period decreased in the 2 nd instar under the same conditions recording (4.67 to 5.67 days). Aphid prey showed non-significant effect on the 3rd instar lifespan, but a strong effect on 4th instar duration. Meanwhile, C. septempunctata larvae fed on aphid from 1st to 3rd instar and showed a significant effect on pupal longevity, averaged 6 days. This period increased when the predator was fed on 4th instar and adults. Aphid instars were offered daily to adult predator till their death recording a high significant effect; adult predators lived longer time between 27.67 and 32.33 days. In the case of adult, predator pre-ovipositional period was never affected by prey instar showing a time ranged between 2.83 and 3.33 days. Singh and Singh (2013) revealed that the 1st, 2nd, 3rd, and 4th instar larvae of C. septempunctata consumed 21.62, 48.03, 73.37, and 102.64 aphids/day, respectively, where the feeding potential of C. septempunctata increased by increasing age of the larvae. Rauf et al. (2013) reported that C. septempunctata showed significant differences with respect to all temperatures, predatory potential of $1 \mathrm{st}, 2 \mathrm{nd}$, 3rd, and 4th larval instars from 21.0 to $37.0,40.5$ to 79.0 , 73.8 to 124.8 , and 342.1 to 481.5 aphids, when adult male and female longevity of $C$. septempunctata ranged from 30.0 to 44.7 and 43.7 to 60.3 days, respectively. Manpoong et al. (2016) recorded that a single C. septempunctata adult consumed an average of $81.55 \pm 15.34$ aphids per day. The total larval period was observed to be $26 \pm 3$ days. The pupal period was found to be $7.5 \pm$ 1.5 days. The adult female lived for $31.5 \pm 1.5$ days and laid $357.45 \pm 22.41$ eggs in her lifetime. Mahyoub et al.
(2013) recorded that C. septempunctata total developmental period occupied from 16 to 21 days under the constant conditions of $23 \pm 2{ }^{\circ} \mathrm{C}$ and $60 \pm 5 \mathrm{RH} \%$.

\section{Predation efficiency and longevity of $C$. undecimpunctata}

First larval instar of $C$. undecimpunctata did not show a significant difference in the rate of predation on the first 3 instars of aphid nymphs, also between the 4th nymphal instar and adult. $C$ undecimpunctata 1st larval instar lasted a period ranged between 3 and 4 days. However, the 2nd larval instar showed a high feeding capacity on 1st and 2nd aphid nymphs, then decreased significantly on the 3rd and 4th prey nymph and aphid adult, respectively. C. undecimpunctata 2nd larval instar lasted an average period of feeding on the different aphid instars from 4.33 to 5.67 days as shown in Table 3. Meanwhile, C. undecimpunctata 3rd larval instar showed significant differences in predation rate on all of aphid's instars (Table 3). It also showed a longer lifespan with significant differences, when feeding on the different aphid instars and recorded an average lifetime ranged between 6.17 and 7.52 days. The 4th larval instar of C. undecimpunctata consumed 131 prey of 1st aphid nymphal instar per day. This rate decreased gradually as consumed only 83 prey of aphid adults. C. undecimpunctata 4th larval instar recorded a period ranged between 5 and 5.33 days to complete development. The predator pupal stage completed its development in a period between 4.33 and 5.5 days. C. undecimpunctata adult showed its predatory efficacy at a minimum rate of 107.33 prey/day at a minimum period of 34.33 day. Meanwhile, adult predator showed a pre-ovipositional period ranged from 4.17 to 5 days. It was always noticed that C. undecimpunctata fed on aphid instars, had consumed a number of prey increased by the increase of predator's age, and decreased by the increase of prey's age. Generally, the adult predator recorded the highest predatory efficacy on the 1st aphid instar, while the 1st larval instar of the predator recorded the lowest predation rate on aphid adult. Accordingly, the daily predation rate of C. undecimpunctata ranged between 14.33 and 140.33 prey/day 
Table 3 Effect of B. brassicae instar on C. undecimpunctata biological parameters

\begin{tabular}{|c|c|c|c|c|c|c|c|c|c|c|c|c|c|c|}
\hline \multirow{3}{*}{$\begin{array}{l}\text { B. } \\
\text { brassicae } \\
\text { instar }\end{array}$} & \multicolumn{14}{|c|}{ C. septempunctata instars } \\
\hline & \multicolumn{2}{|l|}{$1 \mathrm{st}$} & \multicolumn{2}{|l|}{ 2nd } & \multicolumn{2}{|l|}{$3 r d$} & \multicolumn{2}{|l|}{ 4th } & \multicolumn{2}{|l|}{ Pupa } & \multicolumn{2}{|l|}{ Adult } & \multicolumn{2}{|c|}{ Pre-oviposition } \\
\hline & Long.* & Prey** & Long. & Prey & Long. & Prey & Long. & Prey & Long. & Prey & Long. & Prey & Long. & Prey \\
\hline $1 s t$ & $4.00 \mathrm{a}$ & $25.67 \mathrm{a}$ & $5.00 \mathrm{ab}$ & $75.00 \mathrm{a}$ & $7.52 \mathrm{a}$ & $95.00 \mathrm{a}$ & $5.17 \mathrm{a}$ & $131.67 \mathrm{a}$ & $5.17 \mathrm{a}$ & 0.00 & $36.33 \mathrm{a}$ & $136.00 \mathrm{ab}$ & $4.33 \mathrm{ab}$ & $136.00 \mathrm{ab}$ \\
\hline 2nd & $4.17 \mathrm{a}$ & $22.00 \mathrm{a}$ & $5.17 \mathrm{a}$ & $64.67 \mathrm{a}$ & $6.83 \mathrm{ab}$ & $86.00 \mathrm{~b}$ & 5.33 a & $122.67 \mathrm{ab}$ & 5.33 a & 0.00 & $35.67 \mathrm{a}$ & $140.33 \mathrm{a}$ & $4.83 \mathrm{ab}$ & 140.33 a \\
\hline $3 r d$ & $3.67 \mathrm{ab}$ & $23.33 \mathrm{a}$ & $5.17 \mathrm{a}$ & $46.67 \mathrm{~b}$ & $7.00 \mathrm{a}$ & $83.00 \mathrm{bc}$ & $5.00 \mathrm{a}$ & $120.33 \mathrm{~b}$ & $4.33 \mathrm{~b}$ & 0.00 & $34.33 \mathrm{a}$ & $124.67 \mathrm{~b}$ & $4.17 \mathrm{~b}$ & 124.67 b \\
\hline 4th & $3.00 \mathrm{~b}$ & $15.00 \mathrm{~b}$ & $5.67 a$ & $40.33 \mathrm{~b}$ & $6.33 b c$ & $81.33 b c$ & 5.00 & $100.33 \mathrm{c}$ & $5.33 a$ & 0.00 & 34.33 a & $112.67 \mathrm{C}$ & $4.83 \mathrm{ab}$ & $112.67 \mathrm{c}$ \\
\hline Adult & $3.67 \mathrm{ab}$ & $14.33 b$ & $4.33 \mathrm{~b}$ & $46.00 \mathrm{~b}$ & $6.17 c$ & $75.00 \mathrm{C}$ & $17 \mathrm{a}$ & $83.00 \mathrm{~d}$ & $5.50 \mathrm{a}$ & 0.00 & $37.33 \mathrm{a}$ & $107.33 \mathrm{C}$ & $5.00 \mathrm{a}$ & $107.33 \mathrm{c}$ \\
\hline LSD 5\% & 0.79 & 4.53 & 0.74 & 15.34 & 0.65 & 8.12 & $5.33 \mathrm{a}$ & 9.70 & 0.53 & 0.00 & 3.45 & 11.95 & 0.68 & 11.95 \\
\hline
\end{tabular}

*Long. = longevity (/days), ${ }^{* *}$ Prey = number of consumed prey

during its life time. Preferential feeding response could be affected by aphid's species according to Mari et al. (2016) who reported that preferential feeding response and instar durations of C. undecimpunctata when reared on 3 aphid species, i.e., Rhopalosiphum maidis (Maize aphid), Therioaphis trifolii (Alfalfa aphid), and Lipaphis erysimi (Mustard aphid). The duration values in days for 1st, 2nd, 3rd, and 4th instars ranged between 6.50, 5.60, 7.90, and 8.01, respectively, for $R$. maidis. For T. trifolii, it ranged between $5.25,6.0,6.10$, and 7.80 , respectively. Meanwhile, it ranged between 5.23, 5.66, 5.91, and 8.50 days, respectively, for L. erysimi. Female adult beetle lifespan under this study was 35,50 , and 40 days, while it was 30,42 , and 32 days for male adult on maize, alfalfa, and mustard aphids, respectively. They also found that the 1st instar of the predatory beetle devoured 5.50, 10.95 , and 6.5 maize, alfalfa, and mustard aphids, respectively; 2nd instar devoured 20.01, 36.11, and 25.5; the preferential feeding response of 3rd instar larvae was $30.12,46.5$, and 36.5 ; and 4th instar larvae devoured 41.25, 57.12, and 46.11 maize, alfalfa, and mustard aphids, respectively.

Rajput (1994) reported that under laboratory conditions (about $25^{\circ} \mathrm{C}$ ), C. undecimpunctata required 17 days to reach adult stage and at $18{ }^{\circ} \mathrm{C}$, it needed 23.6 days. Hodek (1970) reported that pupal period ranged from 4 to 6 days, with an average of 4.7 days for C. septempunctata. Rodriguez-Soana and Miller (1995) reported that females and males of C. septempunctata lived an average of 47.6 and 46.9 days, respectively, at $20^{\circ} \mathrm{C}$. Singh and Marwaha (2002) reported that C. undecimpunctata grubs can consume 79 Aphis craccivora in a day. Manpoong et al. (2016) recorded that mean consumption of aphids per C. undecimpunctata adult was 80.8 individuals, whereas, 21.76, 55.67, 107.86, and 231.03 aphids were consumed by a single larva during 1st, 2nd, 3rd and 4th instars, respectively.

\section{Predation efficiency and longevity of S. interruptus}

The results shown in Table 4 revealed that the 1st larval instar of S. interruptus consumed a maximum of 20.67 prey/day, and non-significant difference recorded in its predation on all aphid instars. Also, a significant difference in the duration of its lifespan appeared, when fed on different ages of aphids, as it ranged between 2.83 and 3.17 days. On the other side, the predation rate of the 2nd larval instar of the predator increased to record the highest predation rate on the 1st prey instar at a rate of 71 prey/day through a period of 3.17 days before molting to the 3rd instar. The 3rd larval instar of the predator did not significantly exceed the daily predation rate of the 2nd larval instar registering its highest level of 84 prey individuals from the first perennial age per day and also lived a period ranged between 5 and 6.17 days to complete its life. The 4th larval instar recorded the highest predatory level, and non-significant

Table 4 Effect of B. brassicae stages on S. interruptus biological parameters

\begin{tabular}{|c|c|c|c|c|c|c|c|c|c|c|c|c|c|c|}
\hline \multirow{3}{*}{$\begin{array}{l}\text { B. } \\
\text { brassicae } \\
\text { instar }\end{array}$} & \multicolumn{14}{|c|}{ S. interruptus } \\
\hline & \multicolumn{2}{|l|}{$1 \mathrm{st}$} & \multicolumn{2}{|l|}{ 2nd } & \multicolumn{2}{|l|}{$3 r d$} & \multicolumn{2}{|l|}{ 4th } & \multicolumn{2}{|l|}{ Pupa } & \multicolumn{2}{|l|}{ Adult } & \multicolumn{2}{|c|}{ Pre-oviposition } \\
\hline & Long.* & Prey** & Long. & Prey & Long. & Prey & Long. & Prey & Long. & Prey & Long. & Prey & Long. & Prey \\
\hline $1 s t$ & $2.83 \mathrm{ab}$ & $20.67 a$ & $3.17 \mathrm{a}$ & $71.00 \mathrm{a}$ & $6.17 \mathrm{a}$ & $84.00 \mathrm{a}$ & $5.00 \mathrm{a}$ & $101.33 \mathrm{a}$ & $5.33 \mathrm{ab}$ & 0.00 & $21.67 a$ & $105.00 \mathrm{a}$ & $3.67 c$ & $105.00 \mathrm{a}$ \\
\hline 2nd & $2.50 \mathrm{~b}$ & 19.33 a & $3.17 \mathrm{a}$ & $58.00 \mathrm{~b}$ & $5.67 a b c$ & $80.33 a b$ & $5.00 \mathrm{a}$ & $98.00 \mathrm{a}$ & $5.00 \mathrm{c}$ & 0.00 & $17.67 b c$ & $94.00 \mathrm{~b}$ & $4.50 \mathrm{ab}$ & $94.00 \mathrm{~b}$ \\
\hline $3 \mathrm{rd}$ & $2.50 \mathrm{~b}$ & $14.00 \mathrm{c}$ & $3.00 \mathrm{a}$ & $48.67 \mathrm{c}$ & $5.00 \mathrm{c}$ & $75.67 \mathrm{abc}$ & $4.83 a$ & $93.33 \mathrm{a}$ & $4.00 \mathrm{~d}$ & 0.00 & $17.33 \mathrm{C}$ & $91.00 \mathrm{~b}$ & $3.33 c$ & $91.00 \mathrm{~b}$ \\
\hline 4th & $2.83 \mathrm{ab}$ & $18.00 \mathrm{ab}$ & $3.33 \mathrm{a}$ & $43.33 c$ & $5.33 b c$ & $67.67 c$ & $5.17 \mathrm{a}$ & $76.00 \mathrm{~b}$ & $5.17 b c$ & 0.00 & $18.00 b c$ & $79.33 c$ & $4.17 b$ & $79.33 c$ \\
\hline Adult & $3.17 \mathrm{a}$ & $15.33 \mathrm{bc}$ & $3.17 \mathrm{a}$ & $44.67 \mathrm{c}$ & $5.83 \mathrm{ab}$ & $70.67 \mathrm{bc}$ & $5.33 a$ & $76.33 b$ & $5.50 \mathrm{a}$ & 0.00 & 19.00 b & $73.00 \mathrm{c}$ & $4.67 \mathrm{a}$ & $73.00 \mathrm{c}$ \\
\hline LSD 5\% & 0.45 & 3.78 & 0.44 & 7.20 & 0.78 & 10.61 & 0.80 & 10.68 & 0.32 & 0.00 & 1.38 & 10.76 & 0.49 & 10.76 \\
\hline
\end{tabular}

*Long. = longevity (/days), **Prey = number of consumed prey 
Table 5 Consumption and duration (/days) of three predatory larval stages in relation to prey energy reserve

\begin{tabular}{|c|c|c|c|c|c|c|c|}
\hline \multirow{3}{*}{$\begin{array}{l}\text { B. brassicae } \\
\text { instars }\end{array}$} & \multirow{3}{*}{$\begin{array}{l}\text { Total } \\
\text { energy, } \\
\mathrm{cal} / \mathrm{mg}\end{array}$} & \multicolumn{6}{|c|}{ Total larval instars } \\
\hline & & \multicolumn{2}{|c|}{ C. septempunctata } & \multicolumn{2}{|c|}{ C. undecimpunctata } & \multicolumn{2}{|c|}{ S. interruptus } \\
\hline & & Duration & Prey* & Duration & Prey* & Duration & Prey* \\
\hline $1 s t$ & $0.248161 \mathrm{a}$ & $23.83 \mathrm{a}$ & 89.42 a & $21.17 a b$ & $81.83 \mathrm{a}$ & $17.17 \mathrm{a}$ & $69.25 \mathrm{a}$ \\
\hline 2nd & $0.340355 b$ & $24.33 \mathrm{a}$ & $78.33 b$ & $21.50 \mathrm{a}$ & $73.83 b$ & $16.33 a b$ & $63.92 \mathrm{a}$ \\
\hline $3 \mathrm{rd}$ & $0.393617 c$ & $21.00 \mathrm{~b}$ & $67.42 c$ & $20.83 a b$ & $68.18 \mathrm{~b}$ & $15.33 b$ & $57.92 b$ \\
\hline 4th & $0.430161 \mathrm{~d}$ & $23.33 \mathrm{a}$ & $63.17 c$ & $20.17 b c$ & $59.25 \mathrm{C}$ & $16.67 \mathrm{a}$ & $51.25 \mathrm{C}$ \\
\hline Adult & $0.463839 \mathrm{~d}$ & $23.83 \mathrm{a}$ & $60.00 \mathrm{~d}$ & $19.50 \mathrm{c}$ & $54.58 \mathrm{c}$ & $17.50 \mathrm{a}$ & $51.75 c$ \\
\hline \multicolumn{2}{|l|}{ Instar LSD 5\% } & 1.32 & 5.89 & 1.32 & 6.32 & 1.22 & 5.93 \\
\hline \multicolumn{2}{|c|}{ Regression Equation } & \multicolumn{2}{|c|}{$\begin{array}{l}\text { No. of consumed prey }=-42.07+ \\
5.76^{*}\end{array}$} & \multicolumn{2}{|c|}{$\begin{array}{l}\text { No. of Consumed prey }=-40.19+ \\
4.09^{*}\end{array}$} & \multicolumn{2}{|c|}{$\begin{array}{l}\text { No. of consumed prey }=-30.30+ \\
5.98^{*}\end{array}$} \\
\hline \multicolumn{2}{|l|}{ 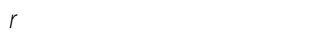 } & \multicolumn{2}{|l|}{0.97} & \multicolumn{2}{|l|}{0.29} & \multicolumn{2}{|l|}{0.98} \\
\hline \multicolumn{2}{|l|}{$R^{2}$} & \multicolumn{2}{|l|}{0.93} & \multicolumn{2}{|l|}{0.081} & \multicolumn{2}{|l|}{0.96} \\
\hline
\end{tabular}

*Prey $=$ number of consumed prey

difference was shown when fed on the 1st, 2nd, and 3rd instar nymphs of the aphid. The results showed that predation rate of adults (73 prey) was at a level close to the daily predation rate of its 4th larval instar (76.33 prey). Also, the adult longevity ranged between 17.33 and 21.67 days in relation to consumed prey instar; the preovipositional period accordingly ranged between 3.33 and 4.67 days (Table 4).

\section{Effect of prey energy reserve on larval consumption and duration}

Results for larval predation efficiency and duration of the 3 studied coccinellid larval species are presented on Table 5. Results showed non-significant deference in the total energy reserves between 4th nymphal instar and adults of $B$. brassicae as prey. Accordingly, the 3 predators, C. undecimpunctata, C. septempunctata, and S. interruptus, did not show a significant difference in feeding consumption on the 4th nymphal instar and B. brassicae adults. Moreover, the average longevity period of the 3 predatory larval stages decreased by increasing the total energy reserves. C. septempunctata larval stage recorded the highest efficiency in daily predation (89.42 prey), when fed on 1st aphid nymphal instar. On the other hand, its larval stage required 21 days, when fed on 3rd nymphal instar of B. brassicae. S. interruptus larval stage showed the lowest predation activity (69.25 prey/ day) and longevity (17.5 days). The lowest correlation value for the 2 nd predator recorded a significant difference between the predators C. septempunctata and $C$. undecimpunctata, and the predation rate was indicated by a decrease in prey age represented by an inverse relationship. Singh and Singh (2013) reported that larvae of C. septempunctata preyed on high numbers of mustard aphids (average 61.42/day) during their larval span. Singh and Singh (2014) also reported average larval duration of C. septempunctata was 11.15 days on mustard aphid. Average pupal period was $5.8 \pm 0.91$ days. The adult male and female survived for 14-18 days and 18-24 days, respectively. Omkar and Srivastava (2003) observed C. septempunctata with the highest and rapid larval development (14.2 days) and greatest daily consumption of mustard aphid (45.3/day). Obtained results are also in accordance with those of Mari et al. (2016), the statistical analysis showed a highly significant difference among predatory efficiency of $C$. septempunctata instars. Imam (2015) recorded that C. septempunctata total larval and pupal durations were $23.4 \pm 0.35$ and 5.3 \pm 0.56 days, respectively. Singh and Singh (2014) also reported average grub duration was 11.15 days on aphid. Average pupal period was $5.8 \pm 0.91$ days. The adult male and female survived for 14-18 and 18-24 days, respectively. Omkar and Srivastava (2003) observed the $C$. septempunctata with a highest rapid larval development (14.2 days) and greatest daily consumption of mustard aphid at the rate of 45.3 aphids/day. Obtained results and according to Mari et al. (2016), statistical analysis showed a highly significant difference between predatory efficiency of $C$. septempunctata larval stage $(F=123.15$ $\mathrm{df}=3, P<0.05)$. Manpoong et al. (2016) recorded that C. undecimpunctata total larval and pupal durations were $23.4 \pm 0.35$ and $5.3 \pm 0.56$ days, respectively.

\section{Generation time}

Results of generation time of the 3 coccinellid species are presented in Table 6 . The results showed that $C$. undecimpunctata required the longest generation time (20.89 days), when fed on B. brassicae 1st nymphal instar. Generation time decreased in case of $S$. interruptus recording (12.22 days), when fed on $B$. brassicae 3rd instar. Sarwar and Saqib (2010) reported that both larvae and adults of $C$. septempunctata when fed on aphid and 
Table 6 Feeding consumption and generation period of three coccinellid species reared on different stages of B. brassicae

\begin{tabular}{|c|c|c|c|c|c|c|c|c|c|c|}
\hline \multirow[t]{3}{*}{ Coccinellid spp. } & \multicolumn{10}{|c|}{ B. brassicae instars } \\
\hline & \multicolumn{2}{|l|}{$1 \mathrm{st}$} & \multicolumn{2}{|l|}{ 2nd } & \multicolumn{2}{|l|}{$3 r d$} & \multicolumn{2}{|l|}{ 4th } & \multicolumn{2}{|l|}{ Adult } \\
\hline & Gener./day* & Prey/day** & Gener./day & Prey/day & Gener./day & Prey/day & Gener./day & Prey/day & Gener./day & Prey/day \\
\hline C. septempunctata & $19.56 \mathrm{~b}$ & $85.47 \mathrm{a}$ & $19.94 \mathrm{~b}$ & $77.56 \mathrm{a}$ & $18.17 \mathrm{~b}$ & $70.36 b$ & $19.67 \mathrm{a}$ & $63.28 \mathrm{a}$ & $21.00 \mathrm{a}$ & $59.44 \mathrm{a}$ \\
\hline C. undecimpunctata & 20.89 a & $72.61 \mathrm{~b}$ & $20.83 a$ & 71.39 a & $19.83 \mathrm{a}$ & $64.11 \mathrm{a}$ & $19.94 \mathrm{a}$ & $58.00 \mathrm{a}$ & $20.78 \mathrm{a}$ & $53.97 \mathrm{a}$ \\
\hline S. interruptus & $14.72 \mathrm{C}$ & $58.08 \mathrm{c}$ & $13.00 \mathrm{c}$ & $52.64 \mathrm{~b}$ & $12.22 \mathrm{c}$ & $49.64 \mathrm{C}$ & $13.28 \mathrm{~b}$ & $43.53 \mathrm{~b}$ & $14.00 \mathrm{~b}$ & $41.58 \mathrm{~b}$ \\
\hline LSD 5\% & 1.16 & 5.65 & 0.82 & 8.97 & 0.96 & 6.07 & 0.91 & 6.12 & 2.06 & 5.77 \\
\hline
\end{tabular}

*Gener./day = generation/day; **Prey/day = number of consumed prey/day

artificial diet showed normal development from egg to adulthood in 20.6 days on aphid prey.33

\section{Conclusion}

Results revealed the effect of prey energy reserve contents $(\mathrm{cal} / \mathrm{mg})$, available as carbohydrates, protein, and lipids in tissues of the cabbage aphid B. brassicae, utilized as prey for 3 coccinellid predators. Different prey nymphal instars and adults affected certain biological parameters of the predators due to their contents of energy reserve. The results reflected that $C$. septempunctata was the most efficient in predation.

\section{Abbreviations}

cal: Calories; Gener.: Generation; Long.: Longevity; $r$ : Regression equation

\section{Acknowledgements}

Not applicable

\section{Cover letter}

We did intend to submit this research paper to The Egyptian Journal of Biological Pest Control and it is not currently under consideration elsewhere.

\section{Authors' contributions}

SIA analyzed and interpreted the data regarding the energy reserve consumed by each predator and shared in writing the manuscript. MMEH performed the laboratory experimentation of the three predatory species and was a major contributor in writing the manuscript. All authors read and approved the final manuscript

\section{Authors' information}

Salama Ibrahim Askar is Ass. Prof. at Plant Protection Department, Faculty of Agriculture, Damanhour University, Egypt.

M.M. El Husseini (CA) is Director of the Center of Biological Control \& IPM at the Faculty of Agriculture, Cairo University, Giza, Egypt.

\section{Funding}

Not applicable

\section{Availability of data and materials}

Not applicable

Ethics approval and consent to participate

Not applicable

\section{Consent for publication}

Not applicable

\section{Competing interests}

The authors declare that they have no competing interests

\section{Author details}

${ }^{1}$ Plant Protection Department, Faculty of Agriculture, Damanhour University, Damanhour, Egypt. ${ }^{2}$ Center of Biological Control \& IPM, Faculty of Agriculture, Cairo University, Giza, Egypt.

Received: 1 April 2020 Accepted: 24 September 2020

Published online: 06 October 2020

\section{References}

Abbott WS (1925) A method of computing the effectiveness of an insecticide. J Econ Entomol 18(2):265-267

Ahsaei SM, Tabadkani SM, Hosseininaveh V, Allahyari H, Bigham M (2013) Differential accumulation of energy by the color morphs of the pea aphid Acyrthosiphon pisum (Hemiptera: Aphididae) mirrors their ecological adaptations. Eur J Entomol 110(2):241-245

Askar SI, El-Aw MA, Draz KAA (2013) Population density of the mealy plum aphid, Hyalopterus pruni (Geoffroy), (Homiptera: Aphididae) and its natural enemies on the weed, Arundo donax, L. at El-Beheira Governorate. J Agric Env Sci Dam Univ Egypt 12(2):93-105

Brandele C, Weisser WW (2001) Variation in escape behavior of red and green clones of the pea aphid. J Insect Behav 14:497-509

Gupta G, Kumar NR (2017) Growth and development of ladybird beetle Coccinella septempunctata L. (Coleoptera: Coccinellidae) on plant and animalbased protein diets. J Asia Pac Entomol 20(3). https://doi.org/10.1016/j.aspen. 2017.07.008

Hodek I (1970) Coccinellids and modern pest management. Bioscience. 20:543552

Imam II (2015) Biological characteristics of elven-spot lady Coccinella undecimpunctata L., reared on Cowpea aphid, Aphis craccivora (Kock), under laboratory conditions. J Plant Prot Path Mansoura Univ 6(6):909-914

Khan MR, Rafique KM (2004) Prey preference and switching behavior of Coccinella septempunctata L. (Coleoptera: Coccinellidae). Int J Agric Biol 4: $110-112$

Lowry OH, Rosembrough NJ, Farr AL, Randdall RJ (1951) Protein measurement with the folic phenol reagent. J Biol Chem 193:267-275

Mahyoub JA, Mangoud AAH, Al-Ghamdi KM, Al-Ghramh HA (2013) Method for mass production the seven spotted lady beetle, Coccinella Septempunctata (Coleoptera: Coccinellidae) and suitable manipulation of egg picking technique. Egypt Acad J Biol Sci 6(3):31-38

Manpoong NS, Firake DM, Behere GT, Rajesh T (2016) Biological attributes and feeding potential of three dominant predators of Lipaphis erysimi (Kaltenbach). J Biol Control 30(3):190-194

Mari JM, Bugti GA, Bin W, Na C (2016) Biological parameters and preferential feeding response of Coccinella undecimpunctata $\mathrm{L}$. on three aphid species. J Entomol Zool Stud 4(4):1306-1310

Obrycki JJ, Kring TJ (1998) Predaceous Coccinellidae in biological control. Annu Rev Entomol 43:295-321

Omkar SS, Srivastava S (2003) Influence of six aphid prey species on development and reproduction of a ladybird beetle, Coccinella septempunctata. Biol Control 43:379-393

Provost C, Lucas E, Coderre D (2006) Prey preference of Hyaliodes vitripennis as an intraguild predator: active predator choice or passive selection? Biol Control 37:148-154

Rajput MR (1994) Behavioral studies of 7-spotted beetles, Coccinella septempunctata Linn. on mustard aphid, Lipaphis erysimi Kalt. MS. Thesis. Dept Entomol Sindh Agri Uni Tandojam, Pak 1994:1-36 
Rauf M, Abdul Rehman AJ, Gillani WA, Ali A (2013) Biology and predatory potential of Coccinella septempunctata L. on Schizaphis graminum aphid under controlled conditions. Pak J Agric Res 26:2

Rodriguez-Soana C, Miller JC (1995) Life history traits in Hippodamia convergens (Coleoptera: Coccinellidae) after selection for fast development. Biol Control 5:389-396

Sarwar M, Saqib SM (2010) Rearing of predatory seven spotted ladybird beetle Coccinella septempunctata L. (Coleoptera: Coccinellidae) on natural and artificial diets under laboratory conditions. Pakistan J Zool 42(1):47-51

SAS Institute (1988) SAS /STAT users guide. SAS Institute, Cary

Singh K, Singh NN (2013) Preying capacity of different established predators of the aphid Lipaphis erysimi (Kalt.) infesting rapeseed-mustard crop in laboratory conditions. Plant Prot Sci 49:84-88

Singh K, Singh NN (2014) Biology and devouring propensity of lady bird beetle, Coccinella septempunctata Linnaeus on rapeseed mustard aphid, Lipaphis erysimi Kaltenbach. Afr J Agric Res 9(1):61-64

Singh MR, Marwaha KK (2002) Feeding potential of some effective predators against maize aphid, Rhopalosiphum maidis (Fitch). Shashpa. 9(1):89-91

Soares AO, Coderre D, Schanderl H (2004) Dietary self-selection behavior by the adults of the aphidophagous ladybeetle Harmonia axyridis (Coleoptera: Coccinellidae). J Anim Ecol 73:478-486

Thompson DJ (1975) Towards a predator-prey model incorporating age structure. The effects of predator and prey size on the predation of Daphnia magna by Ischnura elegans. J Anim Ecol 44:907-916

Van Handel E (1985) Rapid determination of total lipids in mosquitoes. J Am Mosq Control Assoc 1:302-304

Van Handel E, Day J (1988) Assay of lipids, glycogen and sugars in individual mosquitoes: correlations with wing length in field collected Aedes vexans. Am Mosq Control Assoc 4:549-550

\section{Publisher's Note}

Springer Nature remains neutral with regard to jurisdictional claims in published maps and institutional affiliations.

\section{Submit your manuscript to a SpringerOpen ${ }^{\circ}$ journal and benefit from:}

- Convenient online submission

- Rigorous peer review

- Open access: articles freely available online

- High visibility within the field

- Retaining the copyright to your article

Submit your next manuscript at $\boldsymbol{\triangleright}$ springeropen.com 